Rev. Int. Contam. Ambie. 36 (2) 475-483, 2020

DOI: $10.20937 /$ RICA.53541

\title{
PRODUCTION OF LOW-COST BIOCOMPOSITE MADE OF PALM FIBERS WASTE AND GYPSUM PLASTER
}

Producción de biocompuestos de bajo costo a partir de deshechos de fibra de palma y yeso

\section{Wissem GALLALA ${ }^{1 *}$, Hisham Mustafa Mohamed KHATER ${ }^{2}$, Marwa SOUILAH $^{3}$, Khamsa NOURI ${ }^{3}$, Mohamed BEN REGAYA ${ }^{4}$ and Mohamed Essghaier GAIED ${ }^{1}$}

\author{
${ }^{1}$ University of Sousse, ISBAS, Station Square 4000 Sousse, Tunisia \\ ${ }^{2}$ Housing and Building National Research Center, Giza, Egypt \\ ${ }^{3}$ Faculty of Sciences of Gabes, Erriadh City, 6072 Zrig Gabes, Tunisia \\ ${ }^{4}$ CTMCCV, Lacagna Street 1009, Ouardia, Tunis, Tunisia \\ *Corresponding author: wissem.gallala@fsg.rnu.tn
}

(Received: February 2019; accepted: September 2019)

Key words: biomass, plaster, alkaline treatment, physical and mechanical properties

\begin{abstract}
In recent years, natural fibers have been increasingly employed in building materials, due to their proprieties for manufacturing low-cost, renewable, and eco-friendly composites. This study aimed to develop a biocomposite based on local materials: natural fibers and plaster. The natural fibers used are date palm fibers waste from Gabes oasis, Tunisia. In order to characterize these materials, many properties were investigated experimentally (i.e., size, thermal behavior, and microstructural characteristics). On the biocomposite samples, compressive and flexural strength, as well as water absorption tests were performed, properties which increased with the addition of fiber wastes. In order to improve the composite durability, chemical treatments with sodium hypochlorite and resin coating were carried out to decrease surface tension and improve adhesion with the plaster matrix. As a result, the biocomposite showed satisfactory physical, thermal, and mechanical performances, which qualify it as a thermal insulation building material.
\end{abstract}

Palabras clave: biomasa, yeso, tratamiento alcalino, cualidades físicas y mecánicas

\section{RESUMEN}

En años recientes, las fibras naturales se han empleado de manera creciente en materiales de construcción debido a sus propiedades para manufacturar compuestos resistentes, de bajo costo y amigables con el ambiente. Este estudio tuvo como propósito desarrollar un biocompuesto a partir de materiales locales: fibras naturales y yeso. Las fibras naturales utilizadas son fibras de desecho de palmas de dátiles del oasis de Gabes, Túnez. Con el fin de caracterizar estos materiales se investigaron de manera experimental muchas de sus propiedades (por ejemplo, tamaño, comportamiento térmico y características microestructurales). En las muestras de biocompuestos se llevaron a cabo pruebas de resistencia estructural y a la compresión, así como de absorción de agua, propiedades que se incrementaron con la adición de fibras de desecho. Con el fin de prolongar la durabilidad del biocompuesto se realizaron tratamientos químicos con hipoclorito de 
sodio y recubrimiento de resina para disminuir la tensión superficial y mejorar la adhesión a la matriz de yeso. Como resultado, el biocompuesto tuvo un desempeño físico, térmico y mecánico satisfactorio, que lo califica como material viable para aislamiento térmico en la construcción.

\section{INTRODUCTION}

Nowadays cellulose fibers are widely used for reinforcement of mortar, concrete, and polymer composites. Cellulose fiber composites are considered as alternative and competitive materials compared with glass and carbon composites due to their low density, good mechanical properties, eco-friendly nature and low investment cost. Furthermore, the physical and mechanical properties of composites can be improved by chemical treatment (Alawar et al. 2009, Alsaeed et al. 2013, Iucolano et al. 2015, Achour et al. 2017, Oushabi et al. 2017) or by adding a suitable resin to the matrix during its fabrication procedure (Hamzaoui et al. 2014, Fiore et al. 2015, Atiqah et al. 2017, Ghofrani et al. 2017).

In this regard, there are several available works in literature on the use of cellulose fiber materials as reinforcement for concrete and mortar. The natural fibers materials which have been investigated are mainly banana (Iucolano et al. 2015, Mukhopadhyay and Bhattacharjee 2016), bamboo (Agarwal et al. 2014, Javadian et al. 2016, Khatib and Nounu 2017), alfa (Khelifa et al. 2016), flax (Yan and Chouw, 2013, Yan et al. 2014), date palm (Kriker et al. 2005, Benmansour et al. 2014, Djoudi et al. 2014, Boumhaout et al. 2017), etc. Most of these studies revealed that date palm fibers are very promising reinforcing materials and can be used as thermal insulation materials in building.

In Tunisia, the oasis areas, which include cultivated land covered around 45000 ha in 2010 (Ben Salah 2014). Every year after the date fruit harvesting, a considerable amount of date palm wastes is accumulated in huge mounds that ultimately cause environmental problems. In 2006, a total of $90000 \mathrm{t}$ of agricultural wastes were generated in oases (ANGED 2006). Palm leaflets are traditionally used to make utensils and basketworks (Hamza et al. 2013). Nowadays the by-products and waste of date palm are also used as a component for compost preparation (Bchini et al. 2002, Sghairoun and Ferchichi 2011, Latigui et al. 2013, El Khaldi et al. 2016).

In the construction sector the uses of these wastes are very limited, however they possess attractive properties compared to synthetic fibers. The valorization of this vegetable waste in the development of the construction sector has several objectives: economic, technical and environmental. Its abundance in nature and mechanical and thermal properties makes possible to classify it among the strategic resources of renewable energies (Sumathi et al. 2007).

Furthermore, gypsum deposits outcrop in thick layers in southern Tunisia and many plaster manufactures are installed in this region. The produced plaster is mainly used for decorative purposes, although it has interesting thermal properties (Mansour et al. 2013). In the present study, the effect of date palm fibers waste (DPFW) as reinforcing agent on the mechanical properties of plaster-based composite was investigated. The results of an alkaline treatment and drying temperature have also been studied.

\section{EXPERIMENTAL STUDIES}

\section{Materials \\ Plaster}

The plaster (DecoM2) used in this study was provided by the SIPS company and is ISO 9001 certified. The setting behavior of the plaster was characterized by common penetration procedures (knife cut for the initial setting and 40 shore $\mathrm{C}$ for the final setting) according to French standard NF B12-401. The grain size distribution was determined using wet sieving (Table I). The physical and mechanical properties of used plaster are presented in table II and figure $\mathbf{1 .}$

TABLE I. GRAIN SIZE DISTRIBUTION OF THE STUDIED PLASTER

\begin{tabular}{cc}
\hline Grain size & Percentage \\
\hline$+250 \mu \mathrm{m}$ & $\leq 0.2 \%$ \\
$-250+150 \mu \mathrm{m}$ & 1 to $2.5 \%$ \\
$-150+090 \mu \mathrm{m}$ & 12 to $17 \%$ \\
$-90+063 \mu \mathrm{m}$ & 22 to $28 \%$ \\
\hline
\end{tabular}

\section{Palm date fibers}

The ground palm wastes were provided by Chenini Oasis Backup Association, Gabes. Two types of 
TABLE II. PHYSICAL PROPERTIES OF THE STUDIED PLASTER

\begin{tabular}{lc}
\hline Parameter & Value \\
\hline Initial setting (min) & 13 \\
40 shore ${ }^{\circ} \mathrm{C}$ for final setting (min) & 30 \\
Compressive strength (MPa) & 9.2 \\
Flexion strength (MPa) & 4.2 \\
Water absorption (\%) & 35 \\
Porosity (\%) & 38 \\
\hline
\end{tabular}

treatment were applied to the raw fibers. In the first one, sodium hypochlorite was used for $2 \mathrm{~h}$, and the second one consisted of impregnation in an $\mathrm{NaOH}$ solution at various concentrations $(1 \%, 2 \%$ and $4 \%)$ for $24 \mathrm{~h}$. The incorporated fibers were treated in order to clean the surface from impurities and to protect it against water.

The thermal analysis of biomass was conducted in a thermogravimetric analyzer (model SETARAM). The DTG curve (Fig. 2) revealed three distinct

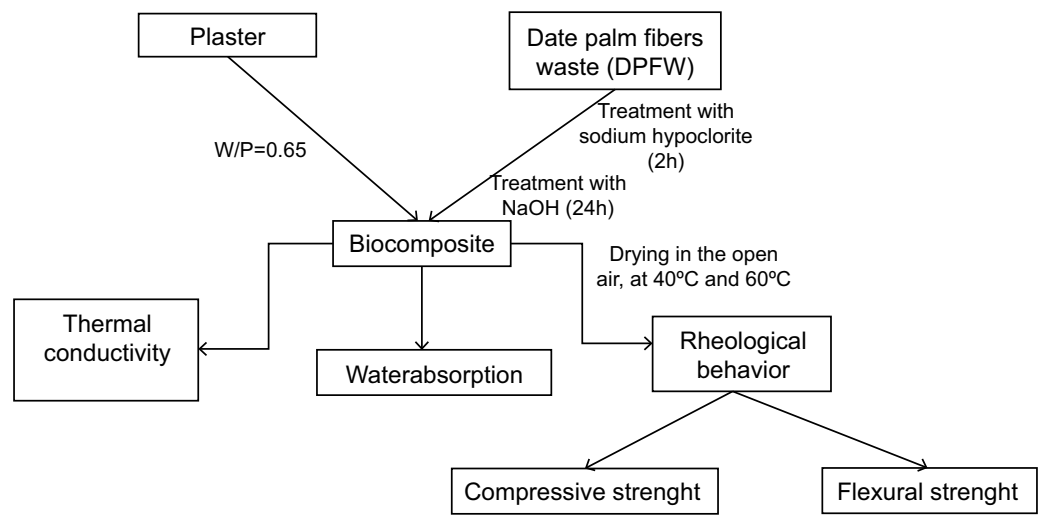

Fig. 1. Different steps of the experimental protocol

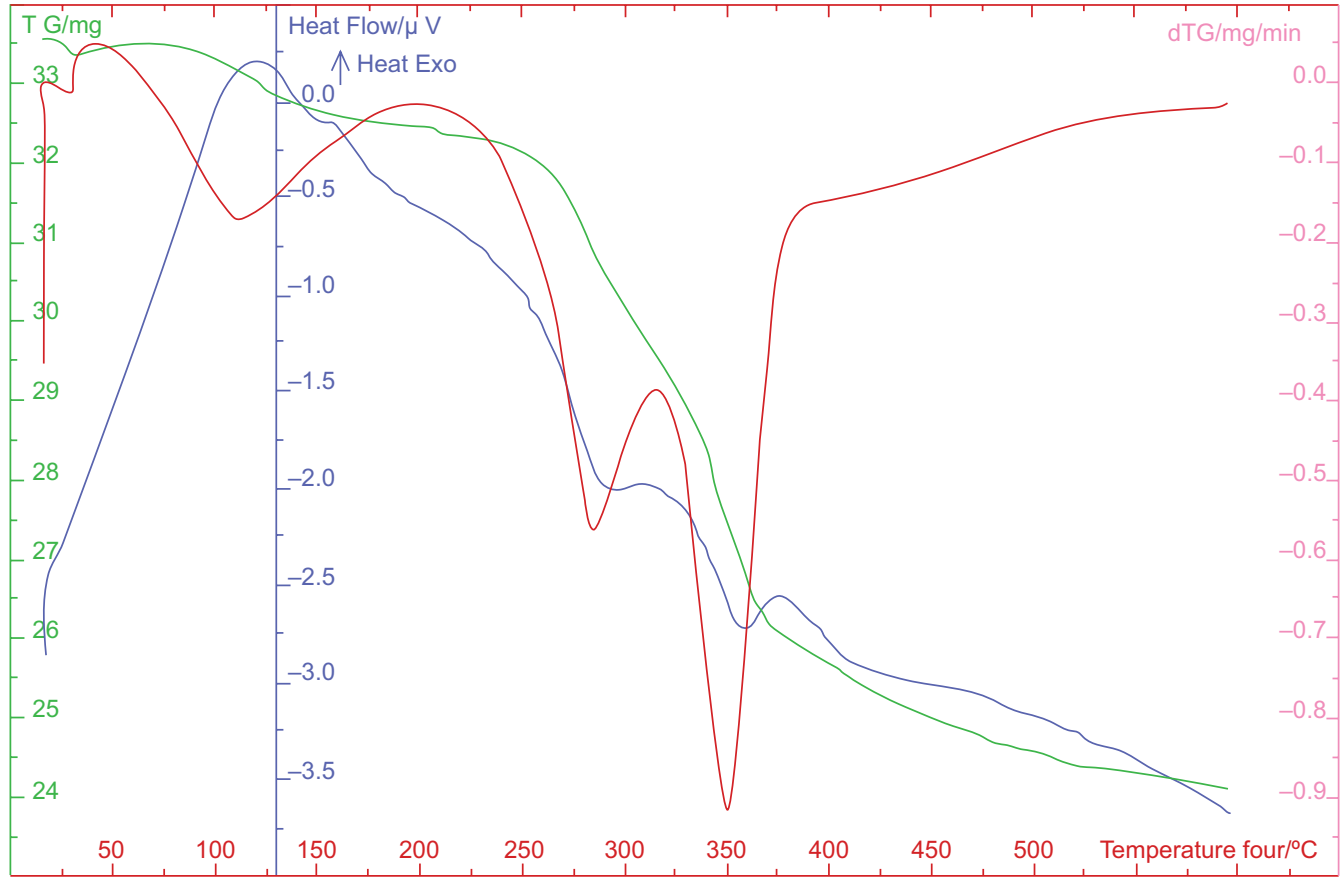

Fig. 2. Thermal analysis of date palm fibers. Thermogravimetry $(\mathrm{TG})$ in $\mathrm{mg}=$ sample loss weight during heating (green curve); DTG $/ \mathrm{mg} / \mathrm{min}=$ the first derivative of TG (purple curve); DSC = differential scanning calorimetry (heat flow/ $\mu \mathrm{v}$; blue curve). Horizontal axis is temperature $\left({ }^{\circ} \mathrm{C}\right)$ 
endothermic peaks corresponding to the decomposition of palm waste:

- In the first zone $\left(25-200{ }^{\circ} \mathrm{C}\right)$ endothermic evaporation of residual water occurred, corresponding to a mass loss of absorbed moisture of approximately $1 \%$.

- The second zone $\left(200-300{ }^{\circ} \mathrm{C}\right)$ is characterized by significant mass loss (about $3.5 \%$ ) due to hemicellulose decomposition (Yang et al. 2004).

- The third zone $\left(300-400{ }^{\circ} \mathrm{C}\right)$ corresponds to the stage of decomposition of cellulose.

The decomposition of lignin took place over a wide range of temperatures up to $400{ }^{\circ} \mathrm{C}$ (Nasser et al. 2016). The microstructures of the palm fiber show that its surface is irregular with many filaments, impurities and pores (Fig. 3a, c).

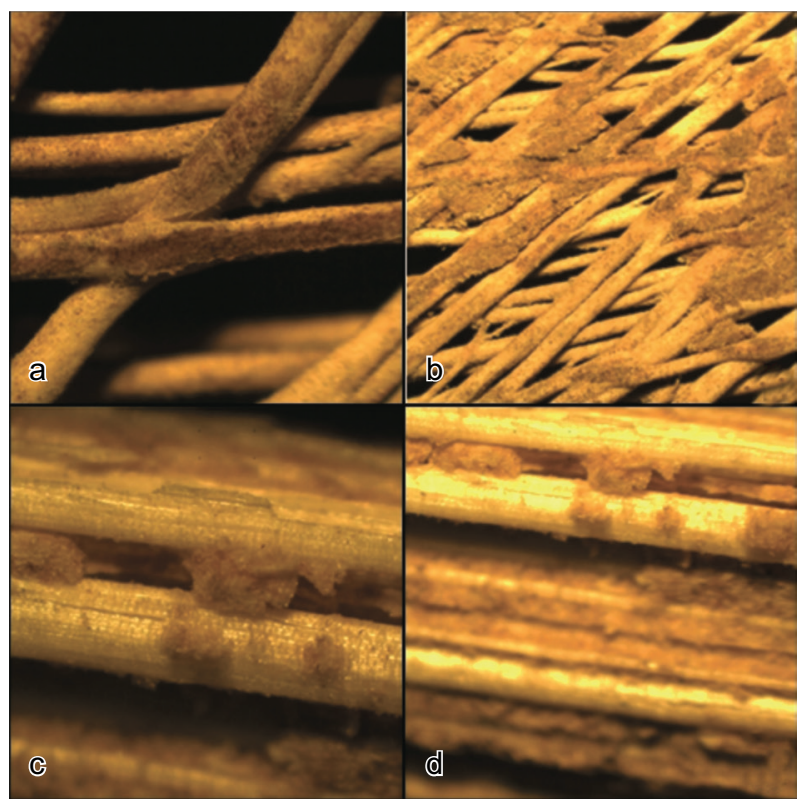

Fig. 3. Microstructure of date palm fibers (a and c) before and (b and d) after alkaline treatment

\section{Analytical methods}

The gypsum composite was prepared using variable mass proportions of DPFW $(7,10,15,17$, and $20 \%$ ). To measure the mechanical strengths, standard prismatic test pieces of $4 \times 4 \times 16 \mathrm{~cm}$ were manufactured with a constant water plaster ratio $(\mathrm{W} / \mathrm{P})$ of 0.65 . These tests were conducted at ages of 3,7 and 28 days. The capillary water absorption coefficient of hardened mortar was determined according to the
BS EN 1015-18 method of test. In order to determine the thermal conductivity of the samples, a Taurus TLP300 Thermal Conductivity Analyzer was used.

\section{RESULTS AND DISCUSSION}

\section{Mechanical strength}

The results of flexural strength are presented in figure $4 \mathbf{a}, \mathbf{b}$. There were not relevant effects of the fibers on the flexural strength from day 3 to 28 , except for the sample incorporating $17 \%$ of fibers in the formulation. The last sample shows an enhancement in mechanical properties at different ages compared to the reference composite. At day 28 , the improvements were approximately $11 \%$ for this sample.

The results of the compression tests before and after washing are presented in figures $\mathbf{4 c}$ and $\mathbf{3 d}$, respectively. An increase in the compressive strength is noted for all composites compared to the control mortar. At day 28 , the compressive strength of the composite with $17 \%$ of fibers was $26 \%$ higher than the reference without fibers. The amelioration in the compressive strength is also attributed to a better fiber-matrix adhesion, since fibers become rougher and thinner after cleaning with water, which may improve their adhesion ability with the matrix (Sawsen et al. 2015).

The addition of $17 \%$ of fibers with different lengths influences the rheological behavior of the plaster. The reduced flexural strength is generally caused by the loss of maneuverability, which is due to poor distribution of the fibers in the fresh state and leads to increasing porosity. Concerning the compressive strength, there is a slight improvement, reaching a maximum for fiber lengths of $20 \mathrm{~mm}$ and then a slow decrease for the lengths of 30 and $40 \mathrm{~mm}$ (Fig. 5). This decrease may be due to unsuitable compactness and workability caused by excess of fibers in the mixture.

\section{Alkaline treatment}

From the previous tests, we found that an addition of $17 \%$ of fibers gives the best results in terms of flexural and compressive strengths. Hence, we incorporated this percentage of fibers in order to develop the resto of the tests.

The mechanical properties of the studied fibers before and after the treatment with different percentages of $\mathrm{NaOH}$ are shown in table III. An improvement in the flexural strength of the DPFW was observed when the alkali treatment was applied. This enhancement can be explained by the removal of the significant parts of lignin, hemicelluloses, wax and oils covering 

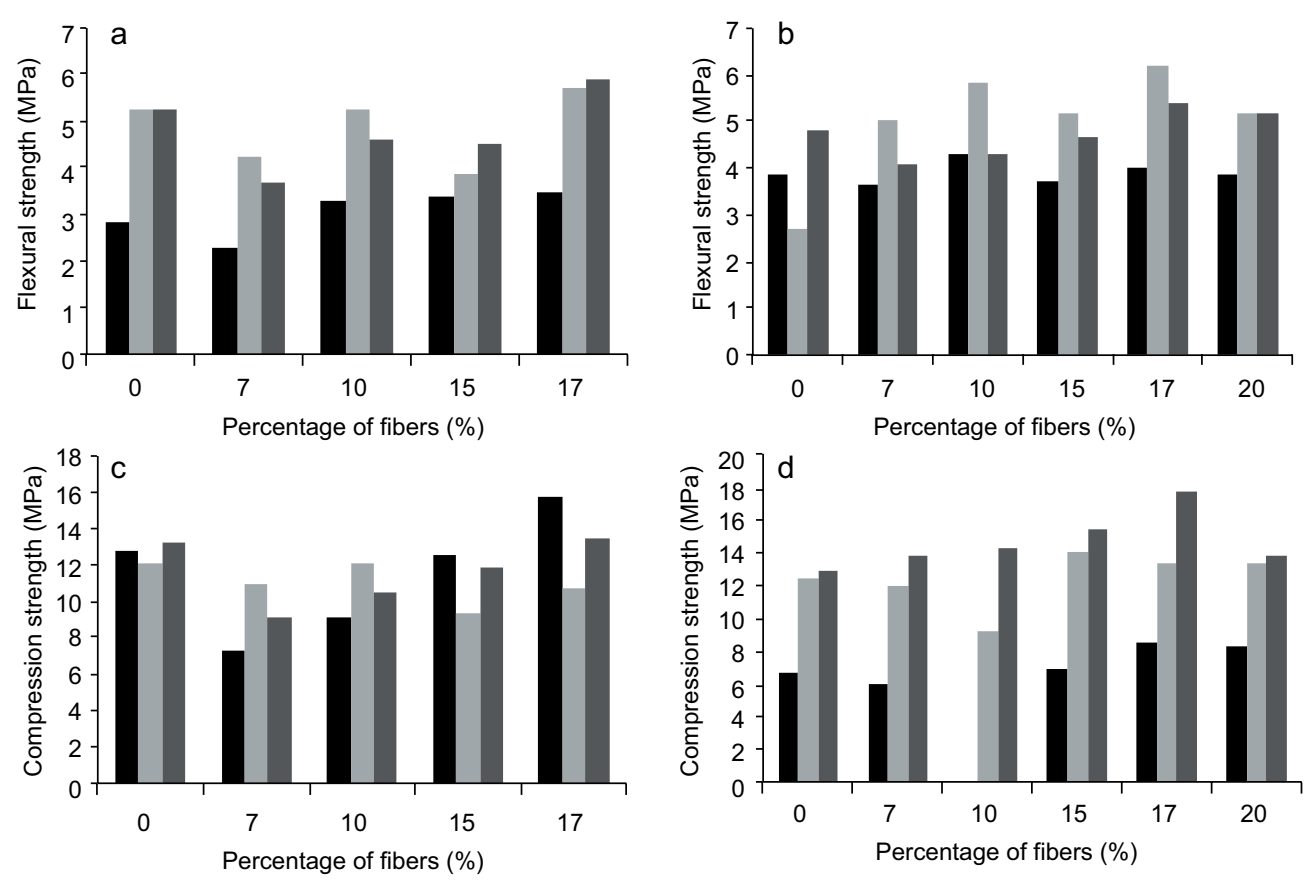

- 3 days 7 days -28 days

Fig. 4. Flexural and compressive strength results of tested composites. (a and c) Before washing; (b and d) after washing

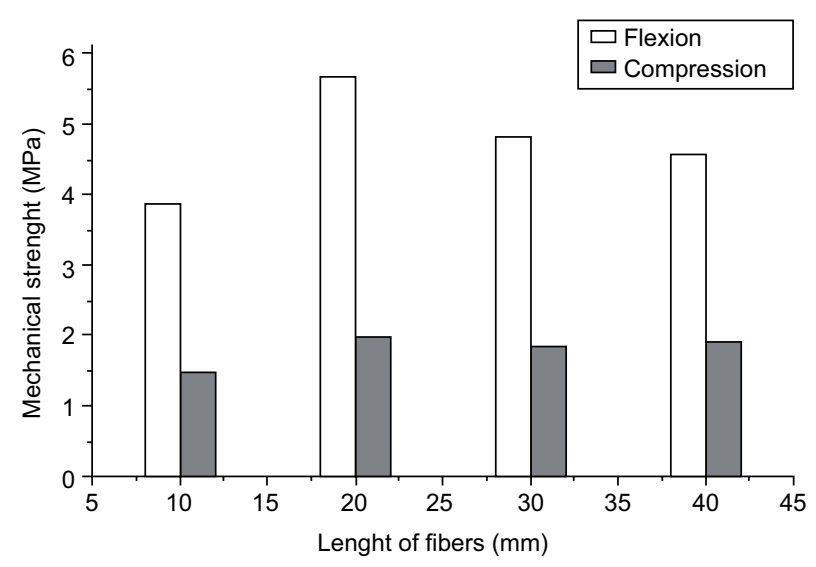

Fig. 5. Effects of fiber length on the mechanical strength

the external surface of the fibers (Li et al. 2007). This modification facilitates the rearrangement of fibrils (Fig. 3b, d) along the direction of flexural deformation. Furthermore, the improvement of strength can be due to the increase of cellulose content and the compactness of the fibers (Sathishkumar et al. 2013).

\section{Water absorption}

Figure 6 shows a correlation between the increasing percentages of DPFW, which tend to increase water absorption. Increasing the percentages of DPFW from 7 to $20 \%$ in the plaster mortar resulted in an increase of water absorption. This behavior is attributed to the porosity of fibers and their hydrophilic character, which is mainly due to the presence of hemicelluloses.

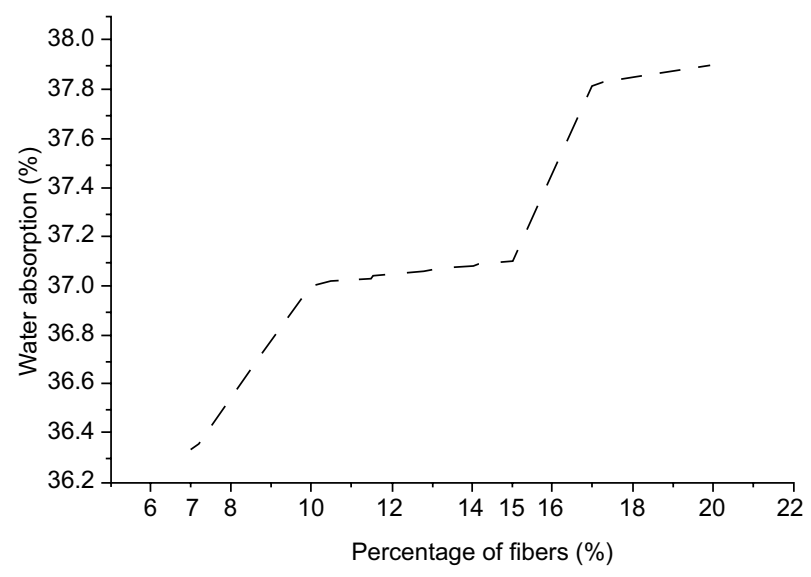

Fig. 6. Water absorption behavior of the studied biocomposite

Plaster tiles of dimension $300 \times 300 \times 20 \mathrm{~mm}$ were made. After immersion in water, the differences in water absorption were minimal (Table IV). However, 
TABLE III. INFLUENCE OF NaOH TREATMENT ON THE FLEXURAL STRENGTH

\begin{tabular}{lcc}
\hline & $\begin{array}{c}\mathrm{NaOH} \text { concentration } \\
(\%)\end{array}$ & $\begin{array}{c}\text { Flexural strength } \\
(\mathrm{MPa})\end{array}$ \\
\hline Composite 1 & 1 & 3.980 \\
Composite 2 & 2 & 5.156 \\
Composite 3 & 4 & 5.859 \\
\hline
\end{tabular}

the absorption increases respectively to 34.84 and $34.41 \%$ for the specimen reinforced with DPFW and for treated fibers. The treatment with epoxy resin decreases water absorption. This decrease is due to the surface modifying treatment and thereby, hydrophilic behavior is relatively reduced (Sreekala et al. 2002).

\section{Comparison with natural insulating composites}

Table $\mathbf{V}$ shows the comparison of thermal conductivity of some composites made with natural fibers and used as construction materials for thermal insulation. The experimentally measured values indicate that the prepared composite in this study presents an excellent thermal performance compared to other composites, as shown in the literature.

According to Djoudi et al. 2014, the thermal conductivity decreases when fiber content increases. The recent study elaborated by Braiek et al. 2017 mentioned that this composite material has good thermophysical properties and can be used in walls or false ceilings. Furthermore, the length of the fibers influences the thermal conductivity; the composite made with short fiber produces many voids, hence leading to low thermal conductivity. The studied composite can be considered as a lightweight material. This value is in the range of data reported in the literature on aggregate concrete, which varied from 0.3 to $0.6 \mathrm{~W} / \mathrm{mK}$. This indicates a promising potential for the development of efficient and safe building insulation materials.

\section{Effect of drying temperature}

The rheological behavior shows the same evolution at a drying temperature of 40 and $60^{\circ} \mathrm{C}$. The flexural and compressive strengths increase with the drying time (Fig. 7). However, these parameters exhibit a large drop for a drying time of $24 \mathrm{~h}$ at $80^{\circ} \mathrm{C}$ (flexural $=0.234 \mathrm{MPa}$, compression $=3.65 \mathrm{MPa}$ )

The increase of mechanical properties can be explained by the acceleration of the curing mechanism of the plaster induced by drying temperature and the increase of fiber-matrix adherence. Nevertheless, high temperature $\left(80^{\circ} \mathrm{C}\right)$ leads the release of volatiles, discoloration and poor mechanical properties.

\section{CONCLUSION}

This experimental study investigated the incorporation of DPFW as reinforcement in a plaster matrix. After carrying out several tests, the optimal percentage of fibers was $17 \%$, and the length was $20 \mathrm{~mm}$.

The incorporation of DPFW improves mechanical strength with the increasing percentage and length of the fibers compared to a control plaster without

TABLE IV. WATER ABSORPTION OF COMPOSITES MADE WITH UNTREATED AND TREATED FIBERS

\begin{tabular}{lccc}
\hline Sample & $\begin{array}{c}\text { Control sample (plaster } \\
\text { without date palm fibers waste) }\end{array}$ & $\begin{array}{c}17 \% \\
\text { fibers }\end{array}$ & $\begin{array}{c}17 \% \text { fibers + } \\
\text { epoxy resin }\end{array}$ \\
\hline Water absorption (\%) & 34.05 & 34.84 & 34.41 \\
\hline
\end{tabular}

TABLE V. COMPARISON OF THERMAL CONDUCTIVITY AND DENSITY OF DPFW WITH SOME MATERIALS USED FOR THERMAL INSULATION IN THE BUILDING

\begin{tabular}{lcll}
\hline Composite & Thermal conductivity $(\mathrm{W} / \mathrm{mK})$ & $\mathrm{r} \mathrm{kg} / \mathrm{m}^{3}$ & References \\
\hline Plaster + 17\% DPFW & 0.52 & 1415.15 & This study \\
Gypsum neat & 0.44 & 1130 & Chikhi et al. 2013 \\
Date palm & $0.072-0.085$ & $187-389$ & Asdrubali et al. 2015 \\
Plaster concrete & 0.89 & 1890 & Djoudi et al. 2014 \\
Plaster concrete + 2\% DPFW & 0.76 & 1200 & Djoudi et al. 2014 \\
Concrete + cork $10 \%$ & 0.96 & 2100 & Panesar et al. 2012 \\
\hline
\end{tabular}

DPFW: date palm fibers waste composites 

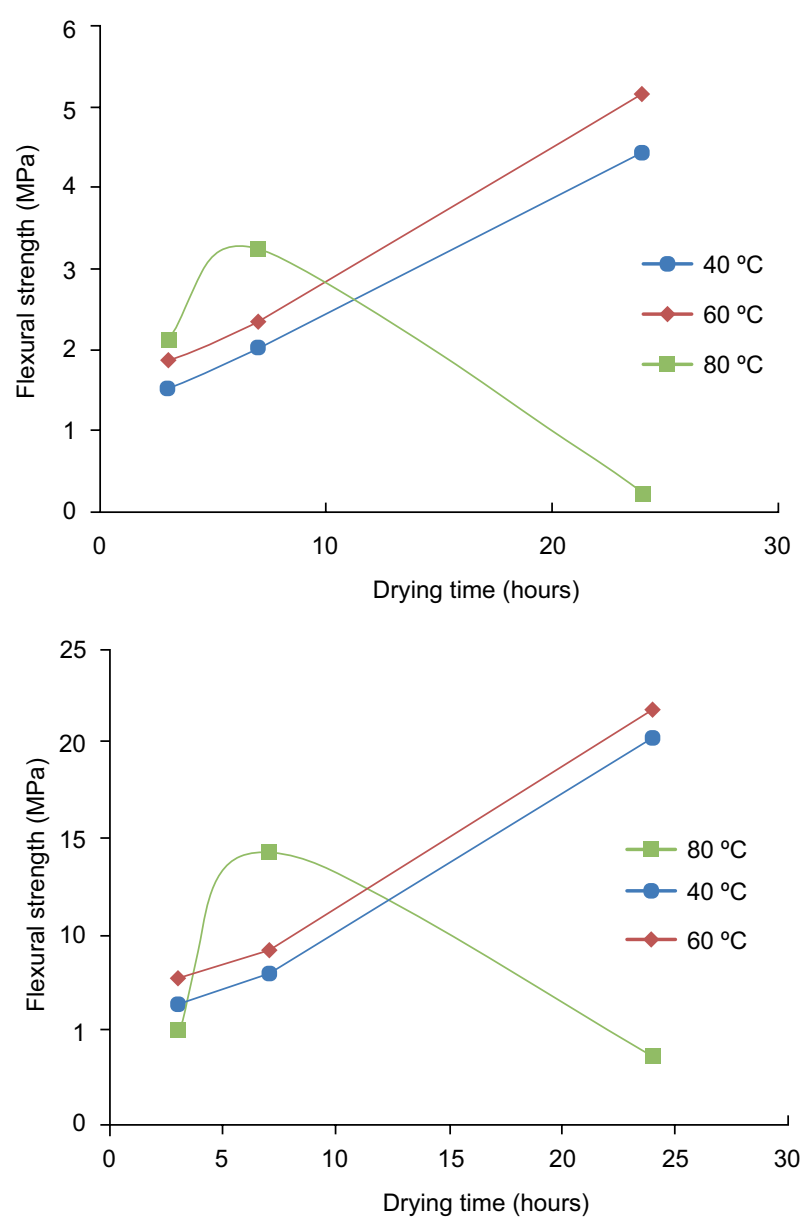

Fig. 7. Flexural and compressive strength results of tested composites under different drying temperatures

them. However, a slight reduction was recorded for a certain percentage due to the loss of workability and lousy orientation of the fibers and the same results for the compressive strength.

The treatment with $\mathrm{NaOH}$ showed an enhancement in the rheological properties (flexion and compression) of the biocomposite and reduced the retardation effect by removing impurities and some soluble compounds. Furthermore, the epoxy treatment effectively contributed to reducing water absorption. The physical properties showed more porous and hydrophilic fibers, possessing high absorption capacity.

In the second part of the experimental study, the drying test at different temperatures on the reinforced-fiber plaster had the following results:

The flexural and compressive strength increased progressively as a function of time, which can be explained by the development of plaster hardening and the increase adhesion between matrix and fiber.
It was demonstrated experimentally that the addition of $17 \%$ DPFW produced a composite with $\mathrm{k}=0.52 \mathrm{Wm}^{-1} \mathrm{~K}^{-1}$ and $\mathrm{r}=1415 \mathrm{~kg} \mathrm{~m}^{-3}$. According to these results, the studied biocomposite can be used as sustainable insulation material in building structures.

\section{ACKNOWLEDGMENTS}

The authors acknowledge the staff of Centre Technique des Matériaux de Construction, de la Céramique et du Verre (CTMCCV) for their assistance in the realization of this work

\section{REFERENCES}

Achour A., Ghomari F. and Belayachi N. (2017). Properties of cementitious mortars reinforced with natural fibers. J. Adhes. Sci. Technol. 31 (17), 1938-1962. DOI: $10.1080 / 01694243.2017 .1290572$

Agarwal A., Nanda B. and Maity D. (2014). Experimental investigation on chemically treated bamboo reinforced concrete beams and columns. Constr. Build. Mater. 71, 610-617. DOI: 10.1016/j.conbuildmat.2014.09.011

Alawar A., Hamed A.M. and Al-Kaabi K. (2009). Characterization of treated date palm tree fiber as composite reinforcement. Compos. Part B-Eng. 40, 601-606. DOI: 10.1016/j.compositesb.2009.04.018

Alsaeed T., Yousif, B.F. and Ku H. (2013). The potential of using date palm fibers as reinforcement for polymeric composites. Mater. Design. 43, 177-184.

DOI: $10.1016 /$ j.matdes.2012.06.061

ANGED (2006). Rapport d'activité sur la valorisation des déchets végétaux en Tunisie. Agence Nationale de Gestion des Déchets. Report. Tunis, Tunisia, 86 pp.

Asdrubali F., D'Alessandro F. and Schiavoni S. (2015). A review of unconventional sustainable building insulation materials. Sustain. Mater. Techn. 4, 1-17.

DOI: 10.1016/j.susmat.2015.05.002

Atiqah A., Jawaid M., Ishak M.R. and Sapuan S.M. (2017). Effect of alkali and silane treatments on mechanical and interfacial bonding strength of sugar palm fibers with thermoplastic polyurethane. J. Nat. Fibers. 15 (2), 251-261. DOI: $10.1080 / 15440478.2017 .1325427$

Bchini H., Hsayoui S. and Aloui S. (2002). Gestion de la matière organique et compostage des palmes sèches dans le milieu oasien. Annales de l'INRAT 75, 299312.

Benmansour N., Agoudjil B., Gherabli A., Kareche A. and Boudenne A. (2014). Thermal and mechanical performance of natural mortar reinforced with date 
palm fibers for use as insulating materials in building. Energ. Buildings 81, 98-104.

DOI: $10.1016 /$ j.enbuild.2014.05.032

Ben Salah M. (2014). Valorisation et recyclage des sous-produits des oasis : acquis et perspectives. Observatoire du Sahara et du Sahel [online]. http:// projet.oss-online.org/ftp/MENA-DELP/EtudesMENADELP/OSSMENA-DELP_Produits-Oasiens. pdf 30/05/2018.

Boumhaout M., Boukhattem L., Hamdi H., Benhamou B. and Nouh F.A. (2017). Thermomechanical characterization of a bio-composite building material: Mortar reinforced with date palm fibers mesh. Constr. Build Mater. 135, 241-250.

DOI: 10.1016/j.conbuildmat.2016.12.217

Braiek A., Karkri M., Adili A., Ibos L. and Nasrallah S.B. (2017). Estimation of the thermophysical properties of date palm fibers/gypsum composite for use as insulating materials in building. Energ. Buildings 140, 268279. DOI: 10.1016/j.enbuild.2017.02.001

Chikhi M., Agoudjil B., Boudenne A. and Gherabli A. (2013). Experimental investigation of new biocomposite with low cost for thermal insulation. Energ. Buildings 66, 267-273. DOI: 10.1016/j.enbuild.2013.07.019

Djoudi A., Khenfer M.M., Bali A. and Bouziani T. (2014). Effect of the addition of date palm fibers on thermal properties of plaster concrete: experimental study and modeling. J. Adhes. Sci. Technol. 28 (20), 2100-2111. DOI: $10.1080 / 01694243.2014 .948363$

El Khaldi R., Daami-Remadi M. and Cherif M. (2016). Biological control of stem canker and black scurf on potato by date palm compost and its associated fungi. J. Phytopathol. 164 (1), 40-51. DOI: 10.1111/jph. 12423

Fiore V., Di Bella G. and Valenza A. (2015). The effect of alkaline treatment on mechanical properties of kenaf fibers and their epoxy composites. Compos. Part B-Eng. 68, 14-21. DOI: 10.1016/j.compositesb.2014.08.025

Hamza S., Saad H., Charrier B., Ayed N. and Charrier-El Bouhtoury F. (2013). Physico-chemical characterization of Tunisian plant fibers and its utilization as reinforcement for plaster-based composites. Ind. Crop. Prod. 49, 357-365.

DOI: 10.1016/j.indcrop.2013.04.052

Hamzaoui R., Guessasma S., Mecheri B., Eshtiaghi A.M. and Bennabi A. (2014). Microstructure and mechanical performance of modified mortar using hemp fibres and carbon nanotubes. Mater. Des. 56, 60-68.

DOI: 10.1016/j.matdes.2013.10.084

Ghofrani M., Ashori A. and Mehrabi, R. (2017). Mechanical and acoustical properties of particleboards made with date palm branches and vermiculite. Polym. Test. 60, 153-159.

DOI: $10.1016 /$ j.polymertesting.2017.03.028
Iucolano F., Caputo D., Leboffe F. and Liguori B. (2015). Mechanical behavior of plaster reinforced with abaca fibers. Constr. Build. Mater. 99, 184-191.

DOI: 10.1016/j.conbuildmat.2015.09.020

Javadian A., Wielopolski M., Smith I.F. and Hebel D.E. (2016). Bond-behavior study of newly developed bamboo-composite reinforcement in concrete. Constr. Build. Mater. 122, 110-117.

DOI: 10.1016/j.conbuildmat.2016.06.084

Khatib A. and Nounu G. (2017). Corrugated bamboo as reinforcement in concrete. P. I. Civil. Eng. Str. B. 170 (4), 311-318. DOI: 10.1680/jstbu.16.00067

Khelifa M.R., Leklou N., Bellal T., Hebert R.L. and Ledesert B.A. (2016). Is alfa a vegetal fiber suitable for making green reinforced structure concrete? Eur. J. Environ. Civ. En. 22 (6), 1-21. DOI: $10.1080 / 19648189.2016 .1217792$

Kriker A., Debicki G., Bali A., Khenfer M.M. and Chabannet M. (2005). Mechanical properties of date palm fibres and concrete reinforced with date palm fibers in hot-dry climate. Cement Concrete Comp. 27 (5), 554-564.

DOI: 10.1016/j.cemconcomp.2004.09.015

Latigui A., Choi J.M. and Regagba Z. (2013). Use of palm (Poenix dactilyfera L.) fiber and sewage sludge co compost as substrates in soilless crop system. Pak. J. Biol. Sci. 16 (14), 651-660.

DOI: $10.3923 /$ pjbs.2013.651.660

Li X., Tabil L.G. and Panigrahi S. (2007). Chemical treatments of natural fiber for use in natural fiberreinforced composites: A review. J. Polym. Environ. 15 (1), 25-33.

DOI: $10.1007 / \mathrm{s} 10924-006-0042-3$

Mansour M.B., Soukaina C.A., Benhamou B. and Jabrallah S.B. (2013). Thermal characterization of a Tunisian gypsum plaster as construction material. Energy Procedia 42, 680-688. DOI: 10.1016/j.egypro.2013.11.070

Mukhopadhyay S. and Bhattacharjee B. (2016). Influence of fibre dispersion on compression strength of banana fibres reinforced concrete. J. Ind. Text. 45 (5), 957-964. DOI: $10.1177 / 1528083714545394$

Nasser R.A., Salem M.Z., Hiziroglu S., Al-Mefarrej H.A., Mohareb A.S., Alam M. and Aref I.M. (2016). Chemical analysis of different parts of date palm (Phoenix dactylifera L.) using ultimate, proximate and thermogravimetric techniques for energy production. Energies 9 (5), 374. DOI: 10.3390/en9050374

Oushabi A., Sair S., Hassani F.O., Abboud Y., Tanane O. and El Bouari A. (2017). The effect of alkali treatment on mechanical, morphological and thermal properties of date palm fibers (DPFs): Study of the interface of DPF-Polyurethane composite. South African J. Chem. Eng. 23, 116-123. DOI: 10.1016/j.sajce.2017.04.005 
Panesar D.K. and Shindman B. (2012). The mechanical, transport and thermal properties of mortar and concrete containing waste cork. Cement Concrete Comp. 34, 982-992.

DOI: 10.1016/j.cemconcomp.2012.06.003

Sathishkumar T.P., Navaneethakrishnan P., Shankar S., Rajasekar R. and Rajini N. (2013). Characterization of natural fibers and composites-A review. J. Reinf. Plast. Comp. 32 (19), 1457-1476.

DOI: $10.1177 / 0731684413495322$

Sawsen C., Fouzia K., Mohamed B. and Moussa G. (2015). Effect of flax fibers treatments on the rheological and the mechanical behavior of a cement composite. Constru. Build. Mater. 79, 229-235.

DOI: 10.1016/j.conbuildmat.2014.12.091

Sghairoun M. and Ferchichi A. (2011). Composting heap palm tree's products in southern Tunisia. J. Environ. Sci. Eng. 5, 886-889.

DOI: $10.17265 / 1934-8932 / 2011.07 .013$
Sreekala M.S., Kumaran M.G. and Thomas S. (2002). Water sorption in oil palm fiber reinforced phenol formaldehyde composites. Compos. Part A: Appl. S. 33(6), 763-777. DOI: 10.1016/S1359-835X (02)00032-5

Sumathi S., Chai S.P. and Mohamed A.R. (2008). Utilization of oil palm as a source of renewable energy in Malaysia. Renew. Sust. Energ. Rev. 12 (9), 2404-2421. DOI: 10.1016/j.rser.2007.06.006

Yan L. and Chouw N. (2013). Behavior and analytical modeling of natural flax fiber reinforced polymer tube confined plain concrete and coir fiber reinforced concrete. J. Compos. Mater. 47, 33-48. DOI: $10.1177 / 0021998312454691$

Yan L., Chouw N. and Jayaraman K. (2014). Flax fiber and its composites-a review. Compos. Part B Eng. 56, 296-317. DOI: 10.1016/j.compositesb.2013.08.014

Yang H.P., Yan R., Chin T., Liang D., Chen P. and Zheng C. (2004). Thermogravimetric analysis-Fourier transform infrared analysis of palm oil wastes pyrolysis. Energ. Fuel 18 (6), 1814-1821. DOI: 10.1021/ef030193m 